\title{
Effect of regular training on lung function in adolescents
}

\author{
Wpływ regularnego treningu na czynność płuc u młodzieży
}

1 Department of Paediatrics and Allergy, Medical University of Lodz, Copernicus Memorial Hospital in Lodz, Lodz, Poland (Kamila Malewska-Kaczmarek ORCID: 0000-0002-6769-839X; Joanna Jerzyńska ORCID: 0000-0002-8042-406X; Daniela Podlecka ORCID: 0000-0002-7443-2223; Ewa Mospinek ORCID: 0000-0002-3690-1631; Iwona Stelmach ORCID: 0000-0002-1475-8221)

2 Department of Social and Preventive Medicine, Medical University of Lodz, Lodz, Poland

Correspondence: Professor Iwona Stelmach, MD, PhD, Department of Paediatrics and Allergy, Medical University of Lodz, Poland, Copernicus Memorial Hospital, Korczak Paediatric Centre, Pitsudskiego 71, 90-329 Lodz, Poland, tel.: +48 4220747 26, fax: +48 426776358 , e-mail: alergol@kopernik.lodz.pl

Abstract The respiratory system of people who actively and regularly practise sport undergoes systematic changes. The development of the respiratory tract and consequently the tidal volumes depend on the type, intensity, severity, duration and frequency of physical effort. Research indicates that tidal volumes achieved by people who regularly practise sport are higher than in those who have less active lifestyles. The assessment of respiratory system functioning is possible by spirometry, which can help in establishing a correct diagnosis and in monitoring the respiratory system in both healthy people and in patients with chronic diseases. The aim of the study was to evaluate selected parameters of lung function in adolescents who actively practise sport and compare them with the general population. The study involved 180 adolescents, aged $12-17$ years. These were 90 boys who actively practised sport in a sports school and 90 boys from a state school who did not train regularly. Sports school students played soccer every day. Spirometry was performed in all the boys who were enrolled in the study. The students who actively played soccer presented significantly higher values of forced expiratory volume in 1 second $\left(\mathrm{FEV}_{1}\right)$, forced vital capacity (FVC), peak expiratory flow $(\mathrm{PEF})$ and maximal expiratory flow $\left(\mathrm{MEF}_{25}\right)$. Moreover, a positive correlation was found between the body mass index (BMI) and $\mathrm{FEV}_{1}, \mathrm{FVC}, \mathrm{PEF}$ and $\mathrm{MEF}_{25}$ in the boys who regularly practised sport; in children who did not train regularly, a similar correlation was found only between BMI and FVC. The results indicate that regular training has a positive effect on spirometry parameters in adolescents.

Keywords: lung function, BMI, sport, adolescents

Układ oddechowy osób aktywnie i regularnie uprawiających sport ulega systematycznym przemianom. Rozwój układu oddechowego, a w konsekwencji objętości oddechowych, zależy od rodzaju, intensywności, ciężkości, czasu trwania i częstotliwości wysiłku fizycznego. Badania wskazują, że objętości oddechowe osiągane przez osoby regularnie uprawiające sport są wyższe niż u tych, które prowadzą mniej aktywny tryb życia. Ocenę funkcjonowania układu oddechowego umożliwia spirometria spoczynkowa, która ułatwia postawienie właściwej diagnozy i monitorowanie układu oddechowego zarówno u osób zdrowych, jaki u pacjentów z chorobami przewlekłymi. Celem badania była ocena wybranych parametrów czynności płuc u młodzieży aktywnie uprawiającej sport w odniesieniu do populacji ogólnej. W badaniu wzięło udział 180 nastolatków w wieku 12-17 lat. Wśród nich było 90 chłopców aktywnie uprawiających sport w szkole sportowej oraz 90 chłopców nietrenujących regularnie, uczęszczających do szkoły niesportowej. Uczniowie szkoły sportowej codziennie trenowali grę w piłkę nożną. U osób zakwalifikowanych do badania wykonano spirometrię spoczynkową. Wśród uczniów aktywnie grających w piłkę nożną zaobserwowano istotnie wyższe wartości natężonej objętości wydechowej pierwszosekundowej $\left(\mathrm{FEV}_{1}\right)$, natężonej pojemności życiowej (FVC), szczytowego przepływu wydechowego (PEF) i maksymalnych przepływów wydechowych $\left(\mathrm{MEF}_{25}\right)$. Stwierdzono również, że u młodzieży regularnie uprawiającej sport istnieje dodatnia korelacja pomiędzy wskaźnikiem masy ciała (BMI) a $\mathrm{FEV}_{1}, \mathrm{FVC}$, PEF oraz $\mathrm{MEF}_{25}$; u dzieci nietrenujących podobną korelację zaobserwowano jedynie pomiędzy BMI i FVC. Uzyskane wyniki wskazują, że regularne uprawianie sportu pozytywnie wpływa na uzyskanie lepszych parametrów w spirometrii spoczynkowej wśród młodzieży.

Słowa kluczowe: czynność płuc, BMI, sport, młodzież 


\section{INTRODUCTION}

$\mathrm{T}$ he respiratory system of people who actively and regularly practise sport undergoes systematic changes. Physical exertion increases not only minute ventilation, but also oxygen consumption. It is estimated that oxygen consumption increases from $250 \mathrm{~mL} / \mathrm{min}$ at rest to $3-5 \mathrm{~L} / \mathrm{min}$ during exercise. This is facilitated by increased minute ventilation and diffusion lung capacity. Improvement of these parameters also facilitates oxygen transport to tissues. Regular training enables athletes to become adjusted to new efficiency conditions ${ }^{(1)}$. The development of the respiratory tract, and consequently the tidal volumes, depend on the type, intensity, severity, duration and frequency of physical effort ${ }^{(2)}$.

According to the World Health Organization (WHO), there is convincing evidence that greater than ordinary physical activity significantly improves health of children and adolescents ${ }^{(3)}$.

Soccer is one of the most popular sport disciplines in the world. It is practised by both men and women of every age group. During a 90-minute match, the competitors playing on the soccer pitch run a distance of approximately $10 \mathrm{ki}-$ lometres, while goal keepers cover a distance of about 4 kilometres.

Professional soccer requires not only physical fitness, but also tactic skills. During a match, each of the competitors needs a lot of energy to sustain the changing pace of running, kicking and jumping ${ }^{(4)}$.

Spirometry is a test that enables the evaluation of vital capacity and its elements, thereby helping to establish a correct diagnosis and monitor the respiratory system in both healthy people and patients with chronic diseases. Children present considerable changeability of tidal volumes with age ${ }^{(5)}$. The reference ranges of spirometry are dependent on age, sex, race and height, but not on physical activity. The expected values for the population with sedentary lifestyles and for people actively practising sport are the same, which significantly narrows the results of lung function tests in athletes. Research indicates that lung volumes achieved by people who regularly practise sport are higher than in those who have less active lifestyles ${ }^{(2,6)}$.

\section{AIM OF THE STUDY}

The aim of the study was to evaluate selected parameters of lung function in adolescents who actively practise sport and compare them with the general population.

\section{MATERIAL}

The study involved 180 adolescents, aged $12-17$ years. These were 90 boys who actively practised sport in a sports school and 90 boys from a state school who did not train regularly.
The exclusion criteria were: a diagnosis of a chronic respiratory disease, no cooperation while testing and contraindications to the planned tests (according to the Polish Society of Allergology).

\section{METHODS}

Spirometry with the use of the MasterScreen machine by Jaeger (Germany) was performed in all the enrolled boys. Lung function tests were performed at the Lung Function Laboratory of the Korczak Paediatric Centre in Lodz, Poland. The measurements were always performed in accordance with the recommendations of the American Thoracic Society (ATS) upon receipt of a written consent of both children and their parents/legal guardians. Spirometry was performed in the sitting position. Each measurement consisted of repeatable two or three correctly performed spirometry tests. Two best measurements of forced expiratory volume in 1 second $\left(\mathrm{FEV}_{1}\right)$ were not different by more than $0.2 \mathrm{~L}$.

\section{Statistical methods}

The tested functions were evaluated using the measures of distribution (mean) and dispersion (standard deviation, 95\% confidence interval as well as minimum and maximum values). Differences between the examined pupils from the two types of schools were determined with the analysis of variance (ANOVA). In order to determine the relationship between the individual parameters, the Spearman's correlation coefficient was calculated. The level of statistical significance was 0.05. All statistical calculations were conducted in Stata/Special Edition, version 14.2 (StataCorp LP, College Station, Texas, USA).

\section{RESULTS}

The study was completed by 180 boys. Their characteristics are presented in Tab. 1. A statistically significant difference in $\mathrm{FEV}_{1}$ values was noted between the tested groups $(p<0.001)$ (Fig. 1). The mean $\mathrm{FEV}_{1}$ values were $105.33 \%$ and $95.5 \%$ for the pupils actively practising sport and for those who did not train regularly, respectively.

The mean values for the Tiffeneau index [a ratio of forced expiratory volume in one second $\left(\mathrm{FEV}_{1}\right)$ to forced vital capacity (FVC)] for the adolescents attending the sports school was $101.89 \%$, whilst for the other group - $103.48 \%$; the difference was not statistically significant (Fig. 2) $(p=0.203)$.

Mean peak expiratory flow (PEF) values differed significantly between the two groups: $101.54 \%$ for the boys from the sports school and $80.04 \%$ for the boys from the regular state school $(p<0.001)$ (Fig. 3). The statistically significant differences were also noted for maximal expiratory flow (MEF) in small airways: $\mathrm{MEF}_{25}(p<0.001)$; the mean value for the boys from the sports school was $96.73 \%$, and for the boys that did not train: 79.07\% (Fig. 4). The values of $\mathrm{MEF}_{50}$ and $\mathrm{MEF}_{75}$ were not different between the groups. 


\begin{tabular}{|c|c|c|c|c|c|c|}
\hline \multirow{2}{*}{$\begin{array}{l}\text { Examined } \\
\text { parameter }\end{array}$} & \multirow{2}{*}{ Studied group } & \multicolumn{4}{|c|}{ Statistical parameters } & \multirow{2}{*}{$\begin{array}{c}\text { Statistical } \\
\text { significance level } \\
(p \text {-value) }\end{array}$} \\
\hline & & $M$ & $S D$ & $95 \% \mathrm{Cl}$ & Min-max & \\
\hline \multirow{2}{*}{ Age [years] } & Athletes & 14.22 & 1.47 & $13.91-14.53$ & $12-17$ & \multirow{2}{*}{$=0.449$} \\
\hline & Non-athletes & 14.06 & 1.28 & $13.80-14.33$ & $12-17$ & \\
\hline \multirow{2}{*}{ Body weight [kg] } & Athletes & 58.26 & 12.66 & $55.60-60.91$ & $31-88$ & \multirow{2}{*}{$=0.118$} \\
\hline & Non-athletes & 60.26 & 13.82 & $57.36-63.14$ & $28-102$ & \\
\hline \multirow{2}{*}{ Height [cm] } & Athletes & 170.14 & 10.54 & $167.94-172.35$ & $141-191$ & \multirow{2}{*}{$=0.724$} \\
\hline & Non-athletes & 169.08 & 9.66 & $167.05-171.10$ & 145-188 & \\
\hline \multirow{2}{*}{$\mathrm{BMI}\left[\mathrm{kg} / \mathrm{m}^{2}\right]$} & Athletes & 19.86 & 2.45 & $19.36-20.38$ & $15.42-25.71$ & \multirow{2}{*}{$=0.011$} \\
\hline & Non-athletes & 20.92 & 3.73 & $20.14-21.70$ & $13.32-30.47$ & \\
\hline \multirow{2}{*}{ FEV 1 best/pred. [\%] } & Athletes & 105.33 & 12.79 & $102.65-108.01$ & 73-141 & \multirow{2}{*}{$<0.001$} \\
\hline & Non-athletes & 95.50 & 14.62 & $92.43-98.56$ & $51-139$ & \\
\hline \multirow{2}{*}{$\begin{array}{l}\text { Tiffeneau index } \\
\mathrm{FEV}_{1} / \mathrm{FVC}[\%]\end{array}$} & Athletes & 101.89 & 7.77 & $100.26-103.52$ & $82-120$ & \multirow{2}{*}{$=0.203$} \\
\hline & Non-athletes & 103.48 & 8.87 & $101.62-105.33$ & $73-118$ & \\
\hline \multirow{2}{*}{ PEF best/pred. [\%] } & Athletes & 101.54 & 15.57 & $98.28-104.80$ & $50-150$ & \multirow{2}{*}{$<0.001$} \\
\hline & Non-athletes & 80.04 & 18.85 & $76.10-83.99$ & $37-122$ & \\
\hline \multirow{2}{*}{ FVC best/pred. [\%] } & Athletes & 102.48 & 11.18 & $100.13-104.82$ & $71-129$ & \multirow{2}{*}{$<0.001$} \\
\hline & Non-athletes & 91.81 & 15.08 & $88.65-94.97$ & $55-131$ & \\
\hline \multirow{2}{*}{$\mathrm{MEF}_{25}$ best/pred. [\%] } & Athletes & 96.73 & 31.26 & $90.19-103.28$ & $41-211$ & \multirow{2}{*}{$<0.001$} \\
\hline & Non-athletes & 79.07 & 18.73 & $75.14-82.99$ & $38-123$ & \\
\hline \multirow{2}{*}{$\mathrm{MEF}_{50}$ best/pred. [\%] } & Athletes & 100.64 & 24.14 & $95.59-105.70$ & $50-171$ & \multirow{2}{*}{$=0.066$} \\
\hline & Non-athletes & 94.10 & 23.31 & $89.22-98.98$ & $34-166$ & \\
\hline \multirow{2}{*}{$\mathrm{MEF}_{75}$ best/pred. [\%] } & Athletes & 102.79 & 18.97 & 98.81-106.76 & $54-156$ & \multirow{2}{*}{$=0.775$} \\
\hline & Non-athletes & 103.92 & 32.46 & $97.12-110.72$ & $46-210$ & \\
\hline $\boldsymbol{U}$ - mean; $\boldsymbol{S D}$ - stanc & eviation; $\mathbf{C l}$ - con & erval. The s & ations for & etric parameters & rred to the pati & \\
\hline
\end{tabular}

Tab. 1. Characteristics of the examined pupils by physical activity

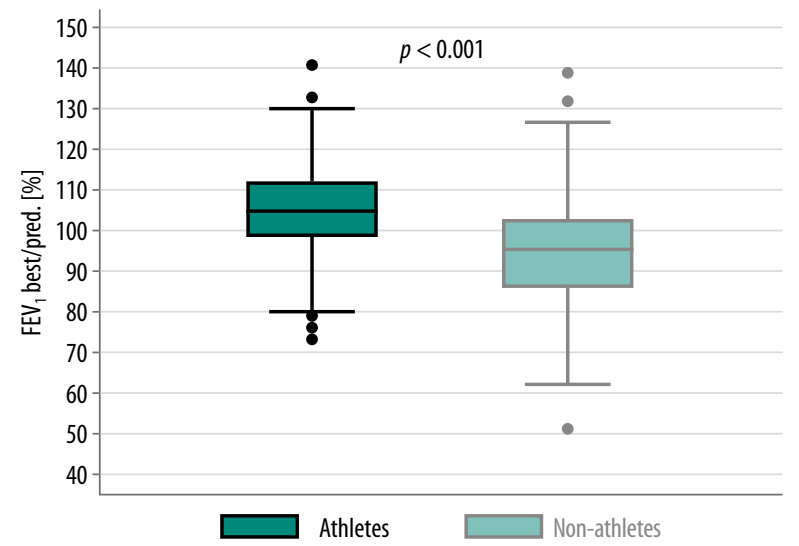

Fig. 1. Results of forced expiratory volume in 1 second (FEV $\left.V_{1}\right)$ [\%] in the examined students by physical activity

The mean value of FVC in the young athletes was $102.48 \%$, while in the boys from the other group - 91.81\%; the difference was statistically significant $(p<0.001)$ (Fig. 5).

The body mass index (BMI) differed significantly between the groups $(p=0.011)$. BMI was lower in the young athletes (mean $19.86 \mathrm{~kg} / \mathrm{m}^{2}$ ) compared with the boys who did not train regularly (mean $20.92 \mathrm{~kg} / \mathrm{m}^{2}$ ).

In the analysis of a relationship between BMI and the individual evaluated parameters in the adolescent athletes, it was shown that there is a positive correlation between BMI

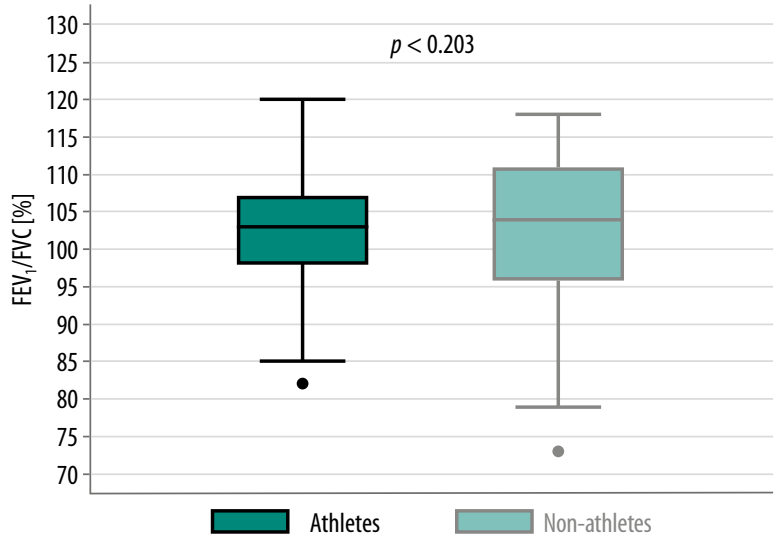

Fig. 2. Results of Tiffeneau FEV ${ }_{1} / F V C$ ratio [\%] in the examined students by physical activity

and $\operatorname{FEV}_{1}(p<0.001), \operatorname{FVC}(p<0.001), \operatorname{PEF}(p=0.006)$ and $\mathrm{MEF}_{25}(p=0.022)$; in the children who did not train, a similar correlation was observed for BMI and FVC $(p=0.020)$ (Tab. 2).

\section{DISCUSSION}

The results indicate that children who regularly practise sport achieve better lung function parameters that those who do not train regularly. The pupils who actively 


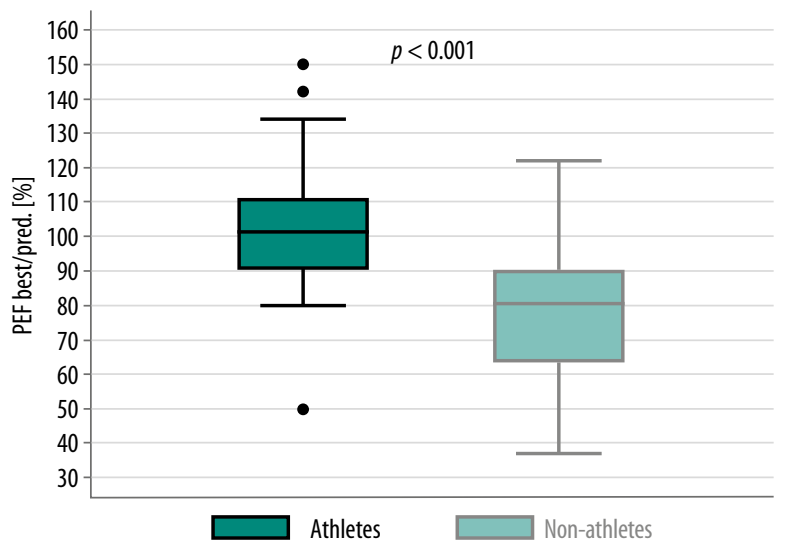

Fig. 3. Results of peak expiratory flow (PEF) [\%] in the examined students by physical activity

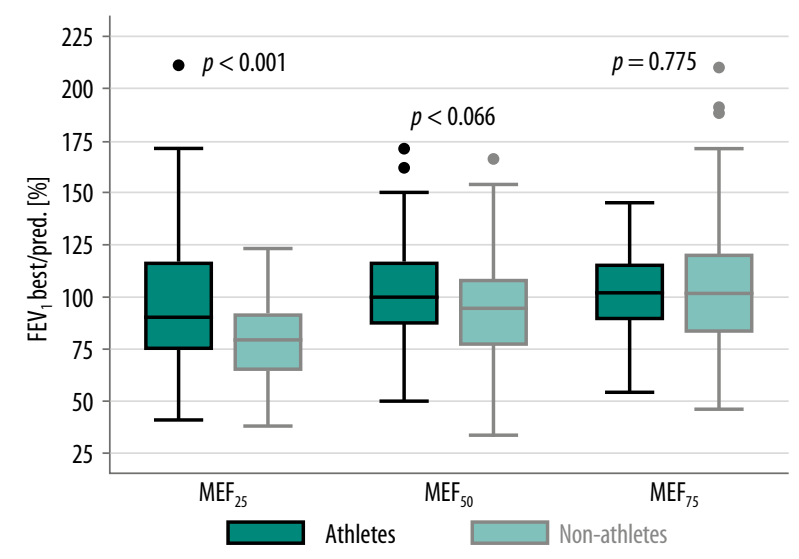

Fig. 4. Results of MEF 25\%, 50\% and 75\% [\%] in the examined students by physical activity

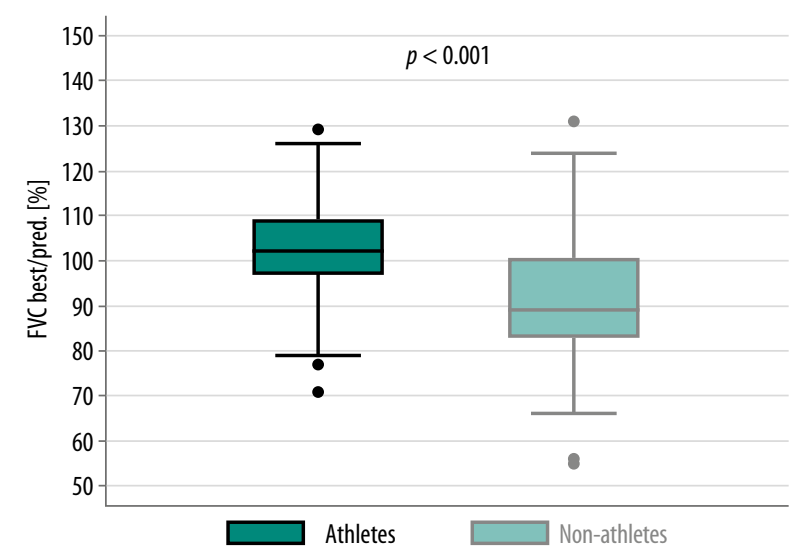

Fig. 5. Results of forced vital capacity (FVC) [\%] in the examined students by physical activity

played soccer presented significantly higher values of $\mathrm{FEV}_{1}, \mathrm{FVC}, \mathrm{PEF}$ and $\mathrm{MEF}_{25}$. Previous research suggests that better spirometry results observed in athletes as compared with the general population are caused by the adaptation of the respiratory system to new physical conditions $^{(2)}$.

The studies performed among athletes indicate that

\begin{tabular}{|c|c|c|}
\hline \multirow{2}{*}{ Examined parameter } & Athletes & Non-athletes \\
\cline { 2 - 3 } & \multicolumn{2}{|c|}{ BMI [kg/m²] } \\
\hline \multirow{2}{*}{ FEV $_{1}$ best/pred. [\%] } & $\mathbf{0 . 4 4 0}$ & 0.129 \\
& $<\mathbf{0 . 0 0 1}$ & 0.226 \\
\hline \multirow{2}{*}{ FVC best/pred. [\%] } & $\mathbf{0 . 4 8 2}$ & $\mathbf{0 . 2 4 5}$ \\
& $<\mathbf{0 . 0 0 1}$ & $\mathbf{0 . 0 2 0}$ \\
\hline \multirow{2}{*}{ PEF best/pred. [\%] } & $\mathbf{0 . 2 8 5}$ & -0.138 \\
& $\mathbf{0 . 0 0 6}$ & 0.194 \\
\hline \multirow{2}{*}{ MEF $_{25}$ best/pred. [\%] } & $\mathbf{0 . 2 4 1}$ & -0.132 \\
& $\mathbf{0 . 0 2 2}$ & 0.215 \\
\hline The upper value is the Spearman's correlation coefficient. \\
The lower value is the statistical significance level. \\
\hline
\end{tabular}

Tab. 2. The correlations between BMI and lung function parameters in the examined athletes and non-athletes

which improves alveolar ventilation. A similar study was conducted in Belgrade. It showed higher FVC and FEV as well as lower Tiffeneau index in athletes ${ }^{(2)}$. These findings are corroborated by research conducted in the United Kingdom, which demonstrated that endurance athletes achieve higher FVC and $\mathrm{FEV}_{1}$ in spirometry, whilst the $\mathrm{FEV}_{1} / \mathrm{FVC}$ ratio is lower compared with the population of people that are not that physically active ${ }^{(7)}$. The evidence suggests that lung volumes of people actively practising endurance sports are higher than in people who do not practise sport ${ }^{(2)}$.

Other authors have observed, however, that static lung volumes are comparable in athletes and non-athletes when the body surface is taken into account ${ }^{(8)}$.

In this study, the evaluated group of pupils regularly trained soccer. None of the boys who had spirometry performed suffered from bronchial asthma, but 10 of the young athletes reported symptoms during or after exercise (cough, dyspnoea, difficulty breathing). Research indicates that $\mathrm{FEV}_{1}$ decreases after exercise in more than $10 \%$ of young people $\mathrm{e}^{(9)}$. This is associated with exerciseinduced bronchoconstriction (EIB). It is estimated that the incidence of EIB is $10-20 \%$ among athletes practising summer sports and $50-70 \%$ among people training winter sports ${ }^{(10)}$. Exercise-induced bronchoconstriction is a common phenomenon in people training soccer ${ }^{(11)}$ but less frequent than in people training volleyball or handball(12).

Irregular physical activity may predispose young people to bronchial hyperresponsiveness and frequent infections. Researchers point out that exercise has a positive influence on respiratory parameters ${ }^{(13)}$. Moreover, literature data suggest that regular and intensive physical activity not only improves general fitness, but may also prevent bronchial asthma ${ }^{(13)}$. Attention should be paid to the variable effect of sport disciplines on lung function. Researchers from Siberia compared basketball, soccer, water polo and handball, and demonstrated that spirometry values were higher in athletes practising water sports. The researchers concluded that regular swimming, even at the basic level, improves respiratory function ${ }^{(6)}$. 
The study presented herein showed that BMI of the boys who regularly trained soccer was in the normal ranges and was significantly lower than BMI in their non-training peers. Obesity in children and adolescents is one of the problems of the $21^{\text {st }}$ century. It is estimated that the number of obese children has increased by 10 -fold within 40 years, and 216 million children are overweight. The WHO indicates that approximately $81 \%$ of adolescents in the world exercise less than recommended ${ }^{(14)}$. According to the recommendations published by the WHO, it is important that children aged 5-17 years be provided with at least 60 minutes of moderate exercise daily. This will have a positive effect on their health. The WHO also recommends that exercises strengthening muscles and bones be practised approximately 3 times a week.

\section{CONCLUSIONS}

Regular physical activity in the examined boys improved spirometry parameters compared with the boys who did not train regularly. Regular training has a positive effect on BMI in adolescents.

\section{Conflict of interest}

The authors do not report any financial or personal connections with other persons or organisations, which might negatively affect the contents of this publication and/or claim authorship rights to this publication.

Funding/Support and role of the sponsor

The study was supported with a grant No. 502-03/2-056-01/502-24-383-18 from the Medical University of Lodz, Poland.

\section{References}

1. Gawlik R: Czy astma sportowców to choroba zawodowa? Alerg Astma Immun 2014; 19: 150-155.

2. Lazovic B, Mazic S, Suzic-Lazic J et al.: Respiratory adaptations in different types of sport. Eur Rev Med Pharmacol Sci 2015; 19: 2269-2274.

3. World Health Organization: Global recommendations on physical activity for health. World Health Organization, Geneva 2010.

4. Stølen T, Chamari K, Castagna C et al.: Physiology of soccer: an update. Sports Med 2005; 35: 501-536.

5. Jat KR: Spirometry in children. Prim Care Respir J 2013; 22: 221-229.

6. Durmic T, Lazovic B, Djelic M et al.: Sport-specific influences on respiratory patterns in elite athletes. J Bras Pneumol 2015; 41: 516-522.

7. Degens H, Rittweger J, Parviainen T et al.: Diffusion capacity of the lung in young and old endurance athletes. Int J Sports Med 2013; 34: 1051-1057.

8. Hagberg JM, Jerg JE $2^{\text {nd }}$, Seals DR: Pulmonary function in young and older athletes and untrained men. J Appl Physiol 1988; 65: 101-105.

9. Cichalewski L, Majak P, Jerzyńska J et al.: Prevalence of exerciseinduced cough in schoolchildren: a pilot study. Allergy Asthma Proc 2015; 36: 65-69.

10. Hildebrand K: Powysiłkowy skurcz oskrzeli. Pneumonol Alergol Pol 2011; 79: 39-47.

11. Ansley L, Kippelen P, Dickinson J et al.: Misdiagnosis of exerciseinduced bronchoconstriction in professional soccer players. Allergy 2012; 67: 390-395.

12. Ziaee V, Yousefi A, Movahedi M et al.: The prevalence of exercise-induced bronchospasm in soccer player children, ages 7 to 16 years. Iran J Allergy Asthma Immunol 2007; 6: 33-36.

13. Rasmussen F, Lambrechtsen J, Siersted HC et al.: Low physical fitness in childhood is associated with the development of asthma in young adulthood: the Odense schoolchild study. Eur Respir J 2000; 16: 866-870.

14. World Health Organization: Taking action on childhood obesity. World Health Organization, Geneva 2018. 